\title{
Nutrition of marsupial herbivores
}

\author{
By I. D. Hume, School of Biological Sciences, University of Sydney, New South Wales \\ 2006, Australia
}

Mammalian herbivores can be divided into two groups on the basis of the principal site of microbial fermentation. Fore-gut fermenters have an expanded and differentiated fore-stomach. Eutherian fore-gut fermenters include sloths, colobid monkeys, hippos, peccaries, camelids and ruminants. Marsupial fore-gut fermenters include the kangaroos, wallabies and rat-kangaroos.

Hind-gut fermenters have an expanded caecum, proximal colon, or both. They can be divided into caecum fermenters and colon fermenters (Hume \& Warner, 1980). In colon fermenters the principal site of microbial fermentation is the proximal colon. A caecum may or may not be present. When it is present, as in the horse, it seems to function largely as a simple extension of the proximal colon. In the only marsupial colon fermenters, the wombats, the caecum is represented by a small vermiform appendix.

In caecum fermenters microbial fermentation is more-or-less confined to an enlarged caecum. Eutherian caecum fermenters include rodents (e.g., beaver, porcupine, guineapig) and lagomorphs (rabbit, hare, pika). Marsupial caecum fermenters include several arboreal species that specialize on Eucalyptus foliage as food, such as the brushtail possum (Trichosurus vulpecula), ringtail possum (Pseudocheirus peregrinus) and greater glider (Petauroides volans). The koala (Phascolarctos cinereus), another Eucalyptus specialist, exhibits features of both caecum fermentation and colon fermentation.

The present paper reviews research on digestive function and nutrient requirements of marsupial herbivores, based on the general outline of herbivore digestive adaptions outlined previously.

\section{Nutrient requirements of marsupial herbivores}

There is currently much debate over the relative importance of phylogeny and food habits in explaining differences in basal metabolic rates (BMR) between groups of mammals (McNab, 1978; Elgar \& Harvey, 1987). Among terrestrial grazer-browsers, macropodid marsupials (i.e., kangaroos and wallabies) and wombats have BMR which are $30 \%$ or more below those of eutherians (McNab, 1978). However, among arboreal folivores both eutherians and marsupials have low BMR.

The relatively low BMR of macropodid marsupials (Dawson \& Hulbert, 1970) is reflected in low maintenance requirements of adult animals for energy (Hume, 1974) and protein (Hume, 1982a), and low tumover rates of water (Hume, 1982b). However, there are exceptions, most of which can be related to differences in habitat between species. As can be seen from Table 1, species which have low maintenance nitrogen requirements are from arid or semi-arid habitats, while those with relatively high requirements are restricted in their distribution to more mesic environments.

Requirements for trace minerals such as copper, molybdenum, cobalt and selenium have also been found to be low, at least in the quokka (Setonix brachyurus,) a small wallaby which thrives on Rottnest Island off the Western Australian coast. Early attempts to graze sheep on this island met with failure when the animals quickly developed a wasting disease now known to be a dual deficiency of $\mathrm{Cu}$ and $\mathrm{Co}$. The limestone-derived sandy soils of Rottnest Island are poor in their status of most minerals. Barker (1960) concluded that the quokka requires only $3 . \mu \mathrm{g} \mathrm{Cu} / \mathrm{kg}$, half the requirement 
Table 1. Maintenance nitrogen requirements of macropodid marsupials ( $\mathrm{mg}$ truly digestible $N / \mathrm{kg}$ body mass ${ }^{0.75}$ per d)

Species
Macropus robustus erubescens
(euro)
M. robustus robustus
(wallaroo)
M. giganteus
(eastern grey kangaroo)
M. eugenii
(tammar wallaby)
M. parma
(parma wallaby)
Thylogale thetis
(red-necked pademelon)

\begin{tabular}{lcl}
$\quad$ Habitat & $\begin{array}{c}\text { Requirement } \\
\text { Arid scrubland }\end{array}$ & \multicolumn{1}{c}{$\begin{array}{c}\text { Reference } \\
\text { Brown \& Main (1967) }\end{array}$} \\
Woodland & 240 & Foley et al. (1980) \\
Forest, woodland & 270 & Foley et al. (1980) \\
$\begin{array}{l}\text { Scrub, heath, } \\
\quad \text { dry forest }\end{array}$ & 250 & Barker (1968) \\
Moist forest & 230 & Hume (1977) \\
Moist forest, rainforest & 477 & Hume (1986) \\
& 530 & Hume (1977)
\end{tabular}

of merino sheep, to maintain normal blood Cu levels. Barker (1961) also showed that this low dietary requirement for $\mathrm{Cu}$ could be markedly elevated by the presence of Mo and inorganic sulphate. Thus, the same three-way $\mathrm{Cu}-\mathrm{Mo}-\mathrm{SO}_{4}$ interaction shown to occur in the induction of $\mathrm{Cu}$ deficiency in ruminants (Dick et al. 1975) apparently also occurs in quokkas. This is not surprising, since both quokkas and sheep are fore-gut fermenters.

Mineral requirements of strict Eucalyptus feeders such as the koala and greater glider must also be low, since eucalypt foliage is often found to have levels of phosphorus, sodium, zinc, $\mathrm{Se}$ and $\mathrm{Cu}$ that are below the levels recommended for domestic sheep and horses (Ullrey et al. 1981). However, exact mineral requirements have been defined for very few marsupials.

Of the vitamins, only vitamin $\mathrm{E}$ has attracted significant attention. This is because of the finding of Kakulas (1961) that captive quokkas from Rottnest Island developed a paralysis of the hind limbs when maintained on a diet of commercial sheep pellets. The same disorder has also been observed with other species of small wallabies maintained on lucerne (Medicago sativa) hay (Hume, 1982a). Histologically, there are marked degenerative changes in the muscles of the hind limbs, lesions typical of a deficiency of vitamin $E$ in the diet. These lesions can be reversed by oral dosing of affected wallabies with $200-600 \mathrm{mg}$ vitamin E daily for several days (Kakulas, 1961), but not with Se. In ruminants, and many other species, Se has been found to be an effective substitute for vitamin E. Wallabies (and rabbits) appear to belong to a small group of animals in which nutritional muscular dystrophy is not prevented by trace amounts of $\mathrm{Se}$.

\section{Digestive function in marsupial herbivores}

Hind-gut fermenters. Colon fermenters, both eutherian and marsupial, are typically large. The only marsupial colon fermenters, wombats, are terrestrial grazers of $25-45 \mathrm{~kg}$ adult body mass. The digestive tract of the common wombat (Vombatus ursinus) is shown in Fig. 1.

The caecum is represented by a small vermiform appendix. The colon is large, about $70 \%$ of total digestive tract capacity, and, like that of the eutherian horse, is characterized by longitudinal bands of muscle (taeniae), between which are found non-permanent semi-lunar folds, or haustra. Contractions of the colon wall, which form the haustra, are responsible for both the caudal propulsion of digesta and the selective 


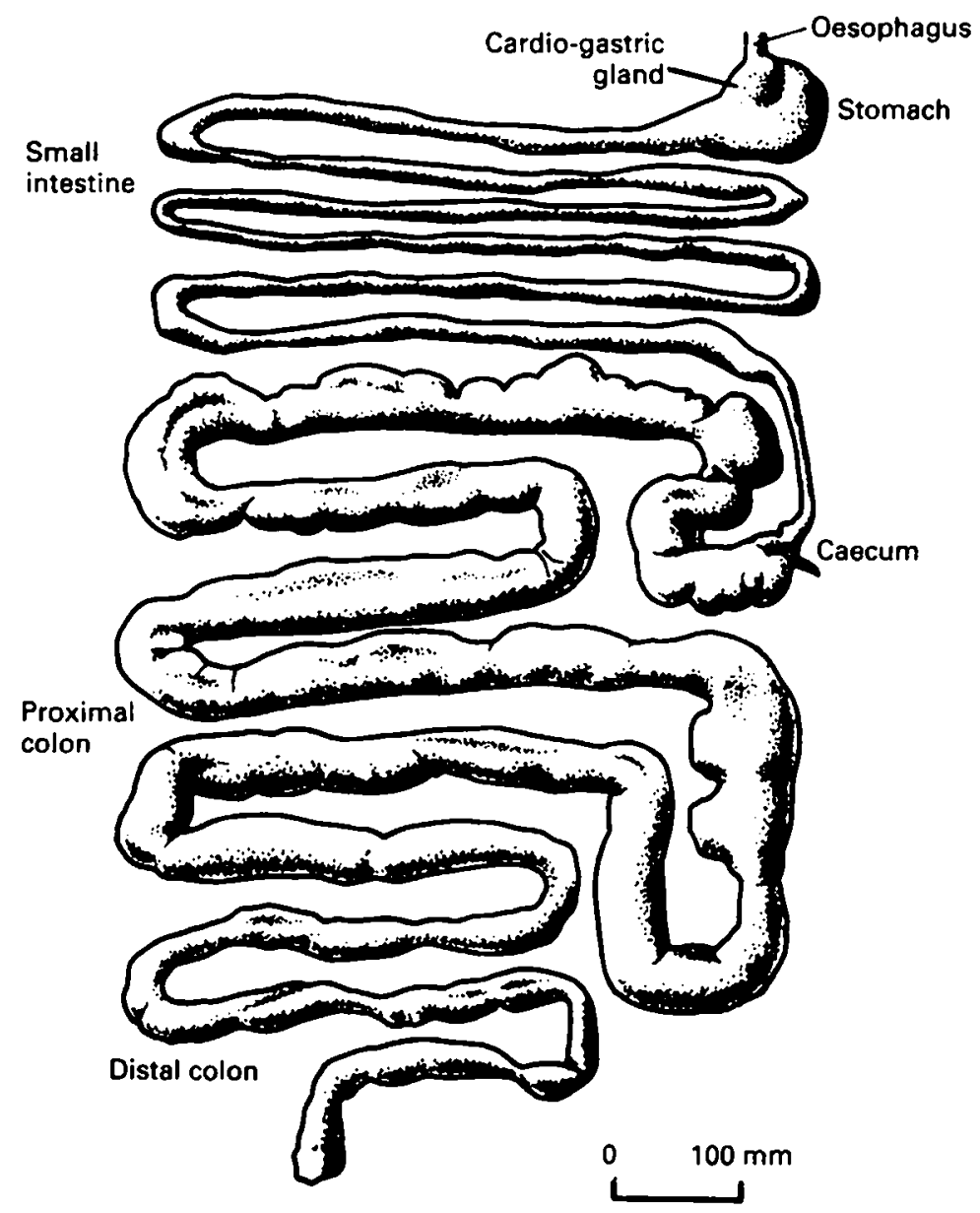

Fig. 1. Digestive tract of the common wombat (Vombatus ursinus), a colon fermenter, $25-45 \mathrm{~kg}$ body mass. Drawn from Hume (1982a).

retention of large particles. The mean retention time (MRT) (Warner, 1981) of particle markers $(62-75 \mathrm{~h}$ in $V$. ursinus) is greater than that of fluid markers $(36-50 \mathrm{~h})(\mathrm{P} . \mathrm{S}$. Barboza, personal communication). Particle markers are also selectively retained in a eutherian colon fermenter, the horse. This maximizes microbial degradation of large particles. Thus, like the horse, the wombat appears well suited to using grasses, which are often of low nutritive value, as a food source.

In contrast to colon fermenters, caecum fermenters are typically small. Marsupial caecum fermenters range from the $750 \mathrm{~g}$ ringtail possums and $1.2 \mathrm{~kg}$ greater glider to $3 \mathrm{~kg}$ brushtail possums. The koala, which exhibits features of both caecum fermenters and colon fermenters, is larger, at 8-13 kg. The digestive tract of the greater glider is shown in Fig. 2, and of the koala in Fig. 3.

In common with eutherian caecum fermenters, in the ringtail possum, greater glider and koala there is selective retention, not of large particles but of fluid and fine particles (mainly bacteria). For example, in the ringtail possum the MRT of fluid was found to be $63 \mathrm{~h}$, and of particles $35 \mathrm{~h}$ (Chilcott \& Hume, 1985). The site of this selective retention of 


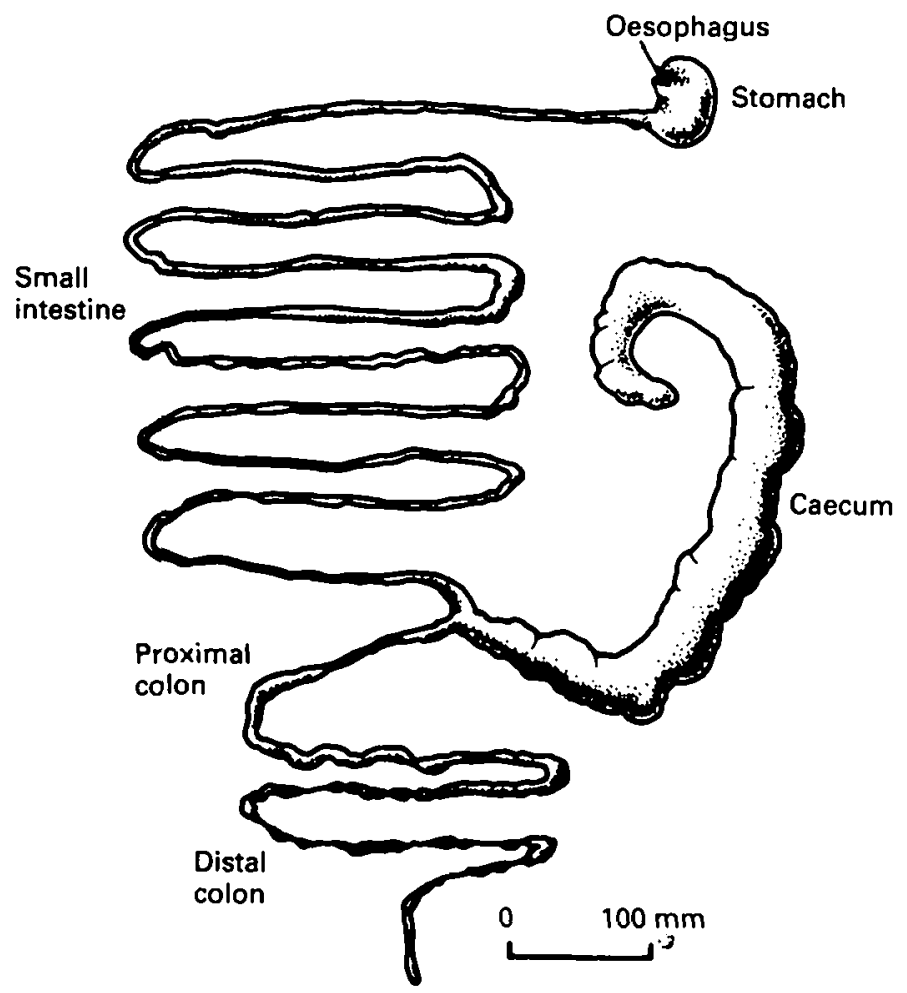

Fig. 2. Digestive tract of the greater glider (Petauroides volans), a caecum fermenter, $1 \cdot 2 \mathrm{~kg}$ body mass. Drawn from Hume (1982a).

fluid in the ringtail possum and greater glider is the caecum, but in the koala both the caecum and proximal colon are involved (Cork \& Warner, 1983).

The consequence of selective retention of fluid is to concentrate digestive effort on potentially more-digestible soluble components and fine feed particles, and also perhaps to maintain a higher concentration of bacteria in the caecum. Larger, potentially less-digestible feed particles are voided relatively quickly, helping to reduce gut fill.

In the smallest caecum fermenter, the ringtail possum, selective retention of fluid and fine particles in the caecum is combined with caecotrophy, a form of coprophagy (Chilcott, 1984). Coprophagy is the ingestion of faeces. Caecotrophy is the ingestion of soft faeces (caecotrophes) which are derived from caecal contents (Hörnicke \& Björnhag, 1980). In ringtails, caecotrophes contained four times the concentration of $N$ found in hard faeces (Fig. 4), but only $58 \%$ of the concentration of neutral-detergent fibre (NDF) (Chilcott \& Hume, 1985). It can be calculated that caecotrophy contributes $58 \%$ of digestible energy intake and twice the maintenance $\mathrm{N}$ requirement of ringtails fed on an entire diet of Eucalyptus foliage (Chilcott \& Hume, 1985). The digestibility of NDF by ringtails ( $45 \%$ ) was greater than by any of the other Eucalyptus feeders, even though it is the smallest species. There is no doubt that caecotrophy is a critical factor in the ringtail's ability to utilize eucalypt foliage as a whole or major food source.

The only other instance of coprophagy described for the eucalypt feeders is in the koala. In this folivore, coprophagy is confined to a 6-week period at the time of weaning, when a very soft material (called 'pap') is taken from the mother's cloaca by the young (Minchin, 1937). The role of this practice is not known, but it may serve to innoculate the hind-gut of the young with the mother's microflora. 


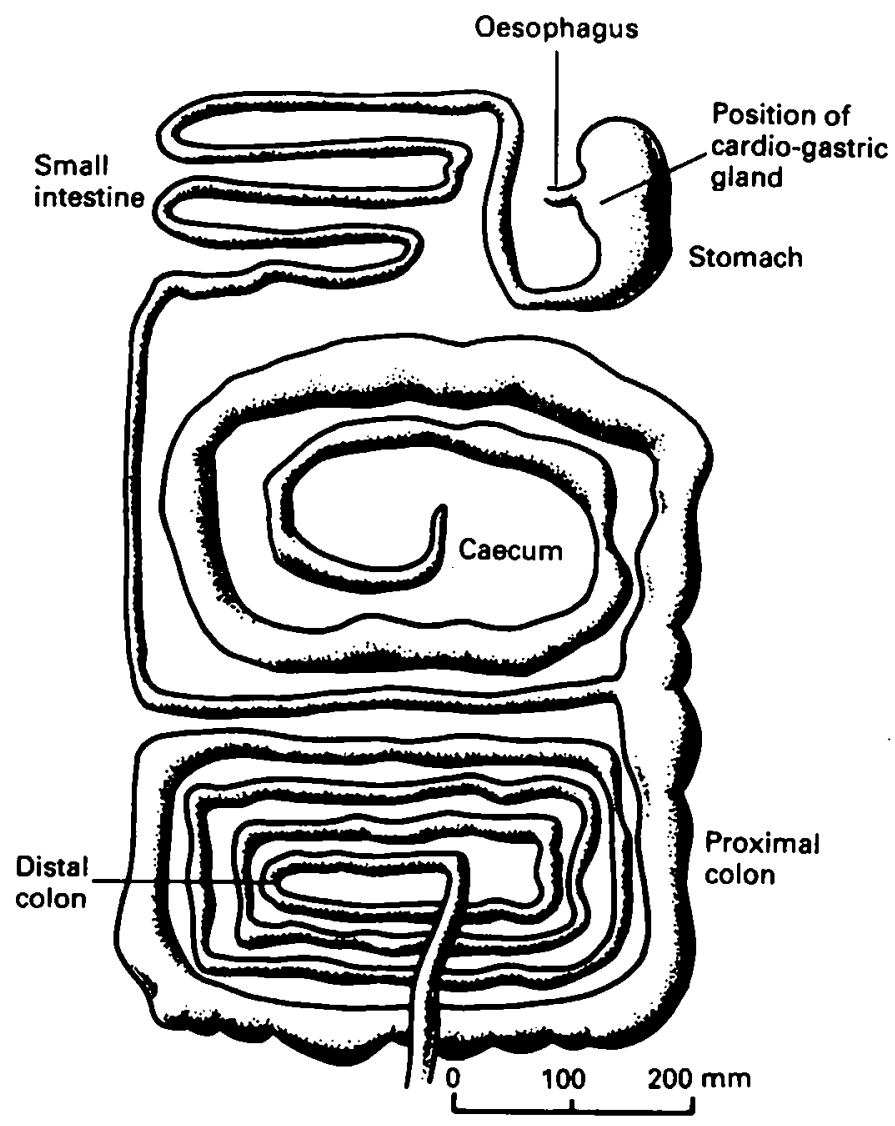

Fig. 3. Digestive tract of koala (Phascolarctos cinereus), a hind-gut fermenter of 8-13 kg body mass, which exhibits features of both colon and caecum fermenters. From Hume (1982a).

Fore-gut fermenters. Marsupial fore-gut fermenters range in body size from the $800 \mathrm{~g}$ potoroos (Potorous spp.), through wallabies from 1 to $15 \mathrm{~kg}$, to the $50-70 \mathrm{~kg}$ eastern grey kangaroo (Macropus giganteus). Foods eaten vary from invertebrates and fungi (in some rat-kangaroos) to browse for the swamp wallaby (Wallabia bicolor) and grasses for $\boldsymbol{M}$. giganteus. Thus the superfamily Macropodoidea (the kangaroos, wallabies and ratkangaroos) offers many opportunities for the study of adaptations of the digestive tract to body size and degree of herbivory.

The structure of the digestive tract of macropodid marsupials (the kangaroos and wallabies) has been described by Hume \& Dellow (1980) and Langer et al. (1980), and its function by Dellow (1982), Dellow \& Hume $(1982 a, b)$ and Dellow et al. (1983). The most striking feature of the stomach of one of the largest kangaroos, $M$. giganteus, is its 'colon-like' tubular morphology (Fig. 5).

Microbial fermentation occurs throughout the fore-stomach, in both the sacciform and tubiform regions. The hind-stomach is the acid-pepsin-secreting region. The external musculature of the fore-stomach wall is organized into three taeniae, as in the proximal colon of the wombat and horse. Semi-lunar folds between the taeniae form the haustrations that give the stomach its colon-like appearance. Contractions of the haustra propel ingesta caudally in such a way that fluid is expressed through the particulate ingesta. As a result, the $50 \%$ excretion time of fluid in $M$. giganteus is only $14 \mathrm{~h}$, 


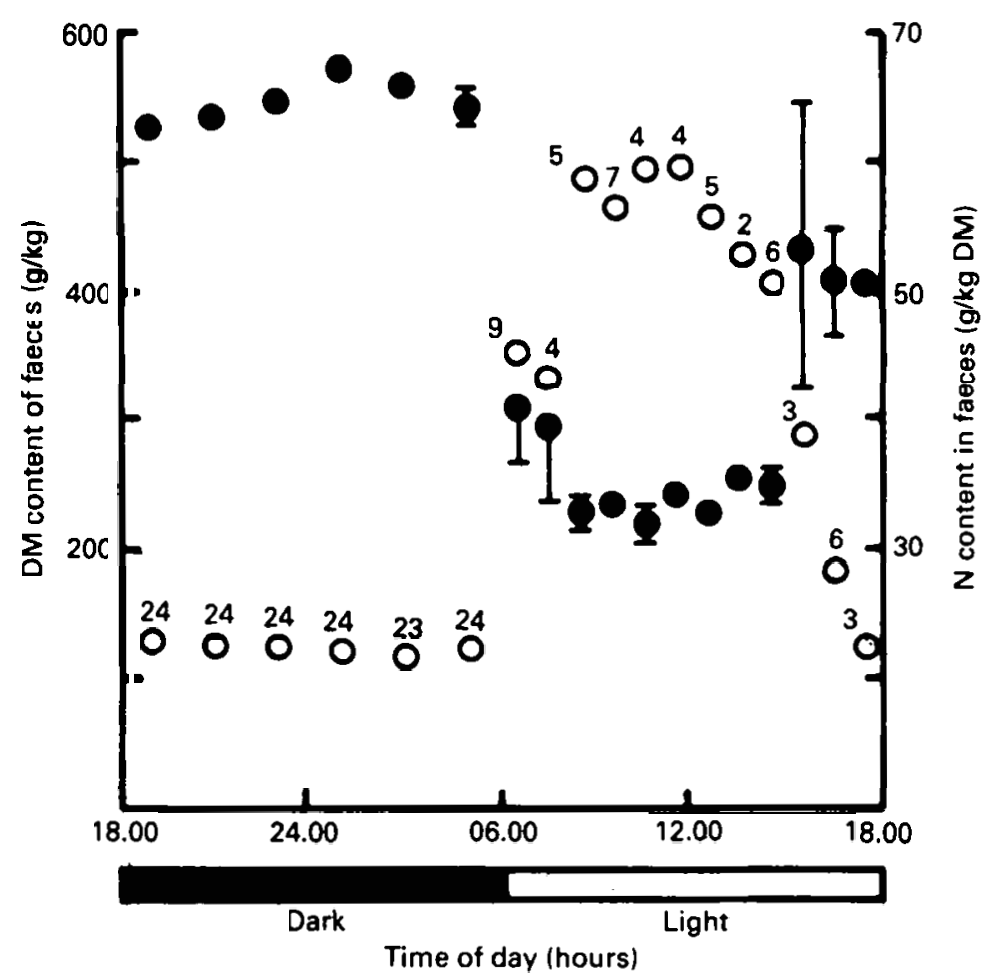

Fig. 4. Changes in dry matter (DM: $(\bullet)$ ) and nitrogen $(O)$ content of ringtail possum (Pseudocheirus peregrinus) faeces over $24 \mathrm{~h}$ (means with their standard errors represented by vertical bars). Values shown above $N$ contents are nos. of measurements for both $N$ and DM. From Chilcott \& Hume (1985).

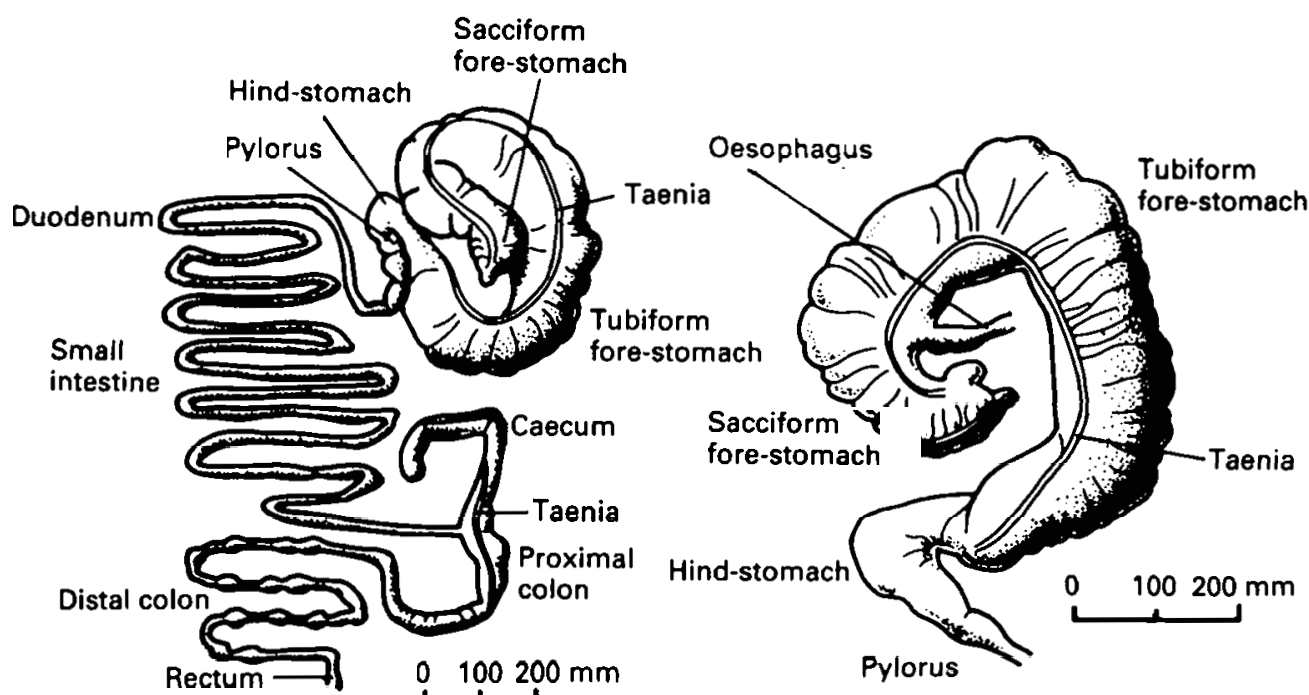

Fig. 5. Digestive tract and stomach of the eastern grey kangaroo (Macropus giganteus), a fore-gut fermenter, $50-70 \mathrm{~kg}$ body mass. From Hume (1982a). 


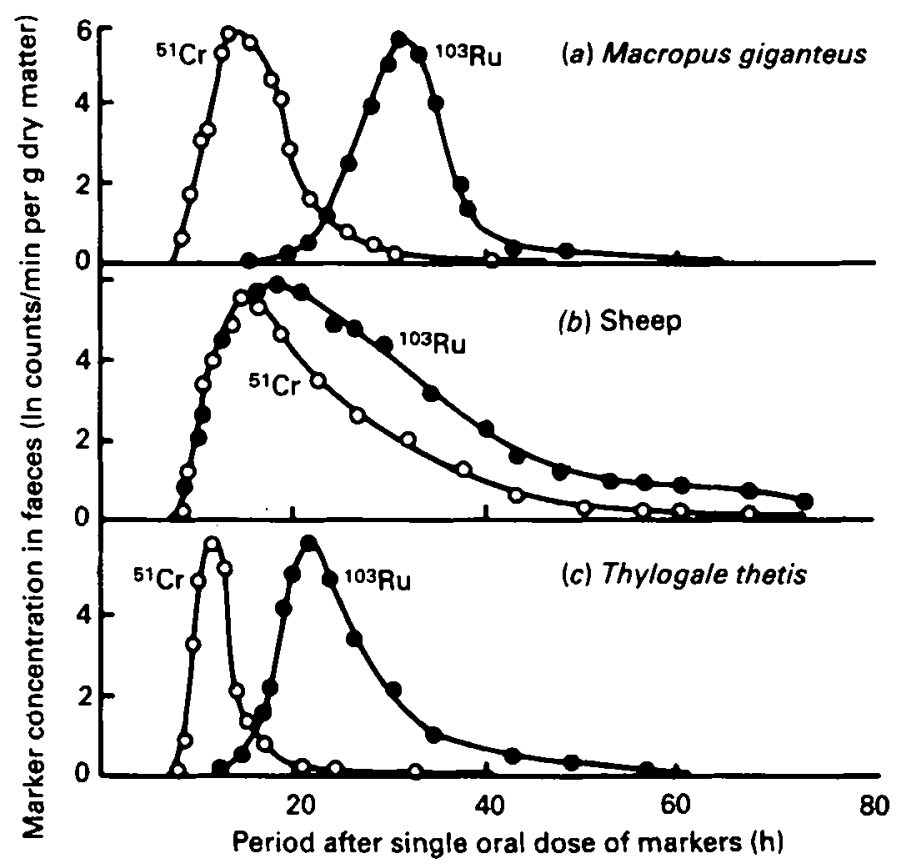

Fig. 6. Pattern of appearance of the fluid marker $\left[{ }^{51} \mathrm{Cr}\right] \mathrm{EDTA}$ and the particle marker $\left[{ }^{103} \mathrm{Ru}\right]$ phenanthroline in the faeces after a single oral dose in (a) the eastern grey kangaroo (Macropus giganteus), (b) the sheep (Ovis aries), and (c) the red-necked pademelon (Thylogale thetis), fed on chopped lucerne (Medicago sativa) hay ad lib. From Hume (1982a).

compared with $30 \mathrm{~h}$ for particulate digesta (Dellow, 1982). The pattern of faecal excretion of fluid and particle markers in M. giganteus is shown in Fig. 6, along with the pattern found in sheep fed on the same diet of chopped lucerne hay. The latter pattern is a result of the mixing of the pulse dose of markers with a large single pool of digesta, concomitant with continuous flow of both markers out of the mixing pool in the reticulo-rumen. The pattern in $M$. giganteus is the result of flow through a basically tubular organ, with only local mixing of the pulse dose of markers with ingesta (Dellow, 1982).

The colon-like morphology of the stomach and the resulting rate and pattern of digesta flow in the kangaroos have a number of consequences. First, because of shorter retention times of digesta in kangaroos than in sheep (a ruminant of similar body size) there is less time for microbial breakdown of plant cell walls in the fore-stomach, and fibre digestibility is generally lower in kangaroos than in sheep fed on the same diet (Dellow \& Hume 1982a). Second, as digesta move through the fore-stomach the substrate fermented is based progressively less on soluble cell contents and more on cell-wall constituents (Dellow \& Hume, 1982b). This is shown in Fig 7.

There is rapid disappearance of soluble carbohydrates in the sacciform region of the fore-stomach, while fibre is digested more-or-less uniformly along the length of the tubiform region. The lack of soluble substrate in the tubiform region may explain why the highest concentrations of protozoa are always found in the sacciform region $\left(1.5 \times 10^{5} / \mathrm{g}\right)$, and why total numbers decrease rapidly along the tubiform region. Alternatively, dilution rates in the tubiform region may be too high to allow protozoa to persist there without being washed out (Dellow et al. 1988). 


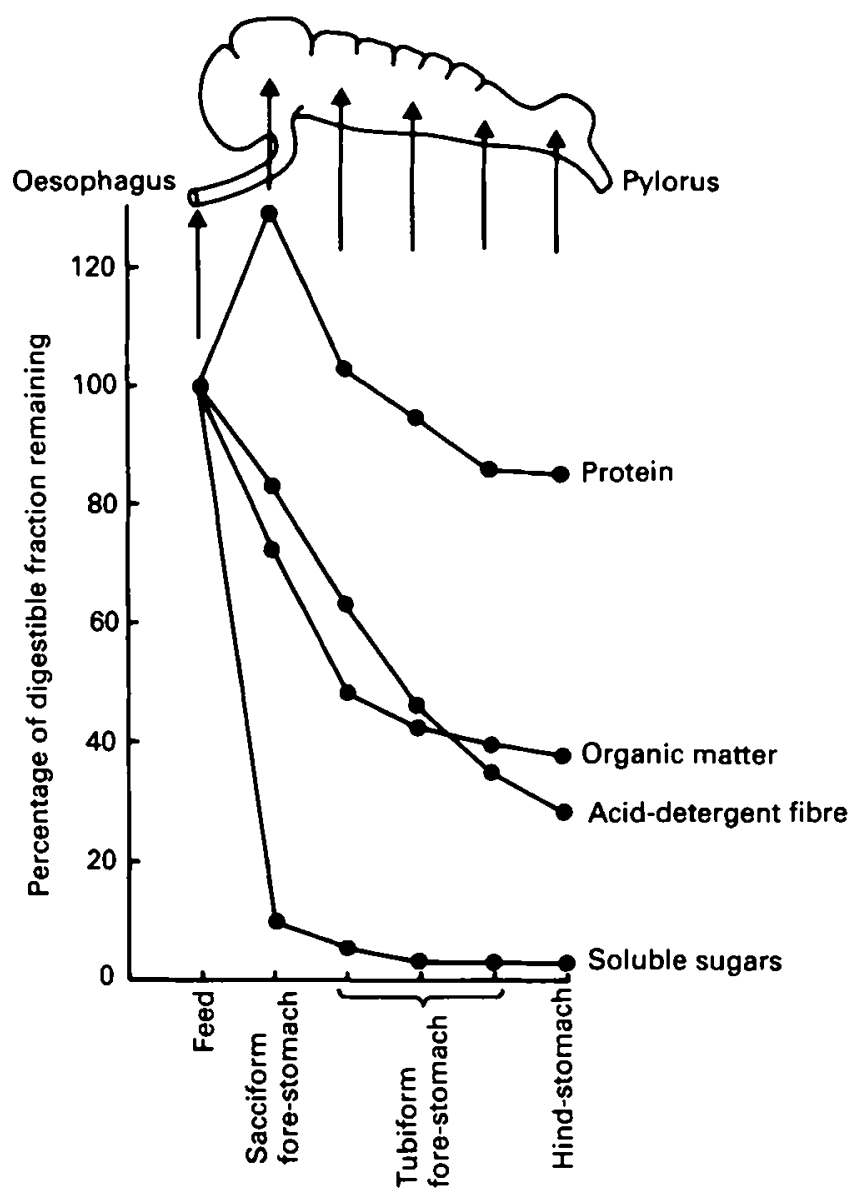

Fig. 7. The disappearance of digestible components of chopped lucerne (Medicago sativa) hay along the stomach of the eastern grey kangaroo (Macropus giganteus). From Dellow \& Hume (1982a,b).

A third consequence of the colon-like morphology of the kangaroo stomach may be that large kangaroos are able to maintain their feed intake better than can ruminants as the fibre content of the diet increases. Hollis (1984) found that when $18 \mathrm{~kg}$ eastern wallaroos (Macropus robustus robustus) were changed from a low-fibre, high-protein diet (chopped lucerne hay) to a high-fibre, low-protein diet (chopped oaten straw) dry matter intake on a metabolic body mass basis fell by only $17 \%$. In contrast, intake by sheep fell by $57 \%$. A similar difference between sheep and red kangaroos ( $M$. rufus) was reported by Foot \& Romberg (1965). This ability of large kangaroos, with their colon-like stomach, to maintain their intake of poor-quality feeds better than can ruminants is similar to the Equidae (Janis, 1976). This has been demonstrated for horses (Darlington \& Hershberger, 1968) and zebra (Foose, 1982). In the equids the tubiform fermentation chamber is to be found in the hind-gut, as the colon itself, rather than in the fore-gut.

The consequences of the colon-like morphology of the kangaroo fore-stomach are seen most clearly in $M$. giganteus, in which the tubiform region comprises $72 \%$ of total stomach capacity (Langer et al. 1980). They are less apparent in some of the smaller wallabies such as the $5 \mathrm{~kg}$ red-necked pademelon (Thylogale thetis), in which the 
tubiform fore-stomach comprises only $40 \%$ of total stomach capacity. For instance, the faecael excretion patterns of fluid and particle markers in $T$. thetis tend to be intermediate between those of $M$. giganteus and the sheep (Fig. 6). Also, the ability of small wallabies to maintain their intake of poor-quality diets appears to be limited. Thus, Hollis (1984) found that dry matter intake by $6 \mathrm{~kg}$ tammar wallabies ( $M$. eugenii) fell by $50 \%$ when changed from the lucerne diet to oaten straw.

Rat-kangaroos. Except for Hypsiprymnodon, which has a simple stomach (Hume, $1982 a$ ), in the rat-kangaroos (the family Potoroidae) the overall plan of the stomach is similar to that of the family Macropodidae. However, the tubiform region of the rat-kangaroo fore-stomach is less than $5 \%$ of total stomach capacity, while over $90 \%$ of stomach capacity is in the sacciform region (Fig. 8). The large sacciform region helps to maximize retention times of ingesta, but the small absolute gut capacity limits the ability of rat-kangaroos to utilize plant cell walls. This is probably the main reason why the diet of rat-kangaroos is not forage (i.e., the aerial structural parts of plants), but nonstructural parts of low fibre content. These include grass seeds, underground (hypo-
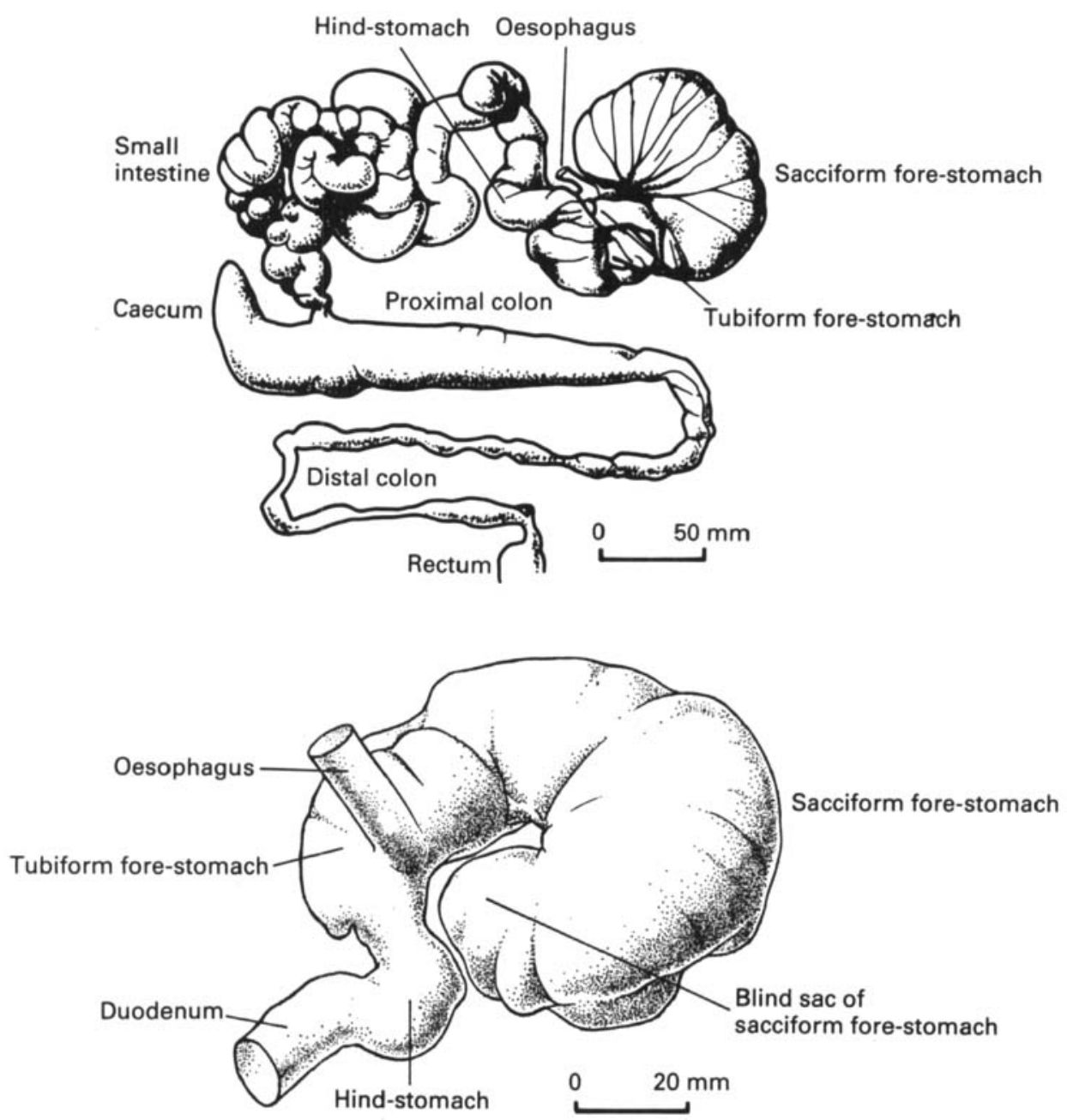

Fig. 8. The digestive system and stomach of the rufous rat-kangaroo (Aepyprymnus rufescens), a fore-gut fermenter, $3 \mathrm{~kg}$ body mass. Drawn from Hume \& Carlisle (1985). 
geous) plant storage organs, such as tubers and swollen tap roots, and hypogeous fungi (Hume, 1982a).

I. R. Wallis (personal communication) has found that on high-starch diets designed to simulate the above natural food items, fibre digestibility in rat-kangaroos is low and variable. This raises the question of the function of the large sacciform region of the potoroine fore-stomach. In fact, some ingesta may not even enter the sacciform fore-stomach, passing instead through the short tubiform region directly into the hind-stomach, and then the small intestine, as demonstrated radiographically by Hume \& Carlisle (1985). These and more recent radiographic studies have led to the suggestion that the primary function of the potoroine fore-stomach may be ingesta storage rather than microbial fermentation of plant cell walls.

Rat-kangaroos are strongly nocturnal, sheltering in grass nests during the day. Feeding bouts during the night can be limited by the presence of predators, and in winter by low ambient temperatures (Rübsamen et al. 1983). Rapid feeding and the capacity to store ingesta are probably important features of the feeding ecology of these small marsupials. Hume \& Carlisle (1985) found that fore-stomach fill was maximal soon after dawn. During the resting phase (daylight) sacciform fore-stomach fill declined as ingesta gradually left via the tubiform fore-stomach into the hind-stomach and small intestine, and as fermentation within the sacciform region proceeded. As yet the quantitative importance of fermentation in the rat-kangaroo fore-stomach and hind-gut has not been established.

\section{Conclusion}

Numerous similarities between marsupial and eutherian herbivore digestive adaptations have been described. The possibility of a common ancestor of these two groups of herbivores is remote. Marsupials are believed to have originated in North America, rafted their way to South America, then moved through Antarctica to Australia when all three continents were part of Gondwanaland (Eisenberg, 1981). Marsupials were established on the Australian land mass about 45 million years ago (mya) when Gondwanaland broke up. This basic marsupial stock is believed to have been basically insectivorous or omnivorous. Herbivorous marsupials evolved in Australia and on surrounding islands from this stock. The terrestrial grazers (kangaroos, wallabies and wombats) evolved to take advantage of grasses (which first appeared in the fossil record about 25 mya) in complete isolation from eutherian herbivores. The many similarities between marsupial and eutherian herbivores described in the present paper, therefore, must be examples of convergence.

\section{REFERENCES}

Barker, S. (1960). PhD Thesis, University of Western Australia, Perth.

Barker, S. (1961). Australian Journal of Biological Sciences 14, 646-658.

Barker, S. (1968). Australian Journal of Experimental Biology and Medical Science 46, 17-32.

Brown, G. D. \& Main, A. R. (1967). Australian Journal of Zoology 15, 7-27.

Chilcott, M. J. (1984). Australian Mammalogy 7, 107-110.

Chilcott, M. J. \& Hume, I. D. (1985). Australian Journal of Zoology 33, 1-15.

Cork, S. J. \& Warner, A. C. I. (1983). Journal of Comparative Physiology 152B, 43-51.

Darlington, J. M. \& Hershberger, T. V. (1968). Journal of Animal Science 27, 1572-1576.

Dawson, T. J. \& Hulbert, A. J. (1970). American Journal of Physiology 218, 1233-1238.

Dellow, D. W. (1982). Australian Journal of Zoology 30, 751-765.

Dellow, D. W. \& Hume, I. D. (1982a). Australian Journal of Zoology 30, 391-398.

Dellow, D. W. \& Hume, I. D. (1982b). Australian Journal of Zoology 30, 767-777. 
Dellow, D. W., Hume, I. D., Clarke, R. T. J. \& Bauchop, T. (1988). Australian Journal of Zoology (In the Press).

Dellow, D. W., Nolan, J. V. \& Hume, I. D. (1983). Australian Journal of Zoology 31, 433-443.

Dick, A. T., Dewey, D. W. \& Gawthorne, J. M. (1975). Journal of Agricultural Science 85, 567-568.

Eisenberg, J. F. (1981). The Mammalian Radiations. Chicago: University of Chicago Press.

Elgar, M. A. \& Harvey, P. H. (1987). Functional Ecology 1, 25-36.

Foose, T. J. (1982). PhD Thesis, University of Chicago, Chicago.

Foot, J. Z. \& Romberg, B. (1965). Australian Journal of Agricultural Research 16, 429-435.

Foley, W. J., Hume I. D. \& Taylor, R. (1980). Bulletin of the Australian Mammal Society 6, 34-35.

Hollis, C. J. (1984). Honours Thesis, University of New England, Armidale.

Hörnicke, H. \& Björnhag, G. (1980). In Digestive Physiology and Metabolism in Ruminants, pp. $707-730$ [Y. Ruckebusch and P. Thivend, editors]. Lancaster: MTP Press Ltd.

Hume, I. D. (1974). Australian Journal of Zoology 22, 13-23.

Hume, I. D. (1977). Australian Joumal of Zoology 25, 407-417.

Hume, 1. D. (1972a). Digestive Physiology and Nutrition of Marsupials. Cambridge: Cambridge University Press.

Hume, I. D. (1982b). Use of Tritiated Water in Studies of Production and Adaption in Ruminants, pp. $195-206$. Vienna: International Atomic Energy Agency.

Hume, I. D. (1986). Australian Journal of Zoology 34, 147-155.

Hume, I. D. \& Carlisle, C. H. (1985). Australian Journal of Zoology 33, 641-654.

Hume, I. D. \& Dellow, D. W. (1980). In Comparative Physiology: Primitive Mammals, pp. $78-89$ [K. Schmidt-Nielsen, L. Bolis and C. R. Taylor, editors]. Cambridge: Cambridge University Press.

Hume, I. D. \& Warner, A. C. I. (1980). In Digestive Physiology and Metabolism in Ruminants, pp. 665-684 [Y. Ruckebusch and P. Thivend, editors]. Lancaster: MTP Press Ltd.

Janis, C. (1976). Evolution 30, 757-774.

Kakulas, B. A. (1961). Nature 191, 402-403.

Langer, P., Dellow, D. W. \& Hume, I. D. (1980). Australian Journal of Zoology 28, 1-18.

McNab, B. K. (1978). Journal of Comparative Physiology 125B, 115-128.

Minchin, A. K. (1937). Records of the South Australian Museum 6, 1-6.

Rübsamen, U., Hume I. D. \& Rübsamen, K. (1983). Journal of Comparative Physiology 153B, $175-179$.

Ullrey, D. E., Robinson, P. T. \& Whetter, P. A. (1981). Australian Joumal of Zoology 29, 839-846.

Warner, A. C. I. (1981). Nutrition Abstracts and Reviews 51B, 789-820. 